\title{
体脂肪率（\%Fat）推 定法の比較
}

\author{
小宮 秀 一* 小室 史 恵* 吉川和 利* \\ A COMPARISON OF METHODS FOR ESTIMATING \\ PERCENT BODY FAT
}

\author{
SHUICHI KomiYA, TOSHIE KomURO AND KaZUTOSHI KIKKAWA*
}

\begin{abstract}
A comparative study was conducted between two independent methods to estimate body fat in a total population of 27 Japanese females (aged 20-40). The two methods dealt with different body component parameters. Body fat was estimated (1) in terms of skinfolds according to the formula of Nagamine and Suzuki ('64), who used triceps and subscapular skinfolds, and (2) in terms of total body water based on the analysis of the dilution of orally ingested deuterium oxide $\left(D_{2} \mathrm{O}\right)$ in urine. The estimate of the percent body fat by each of the two methods showed significant difference. The skinfold estimate of percent body fat was significantly lower than the $\mathrm{D}_{2} \mathrm{O}$ estimate. The best combination of four variables for predicting total body water was found to be humerus breadth, femur breadth, abdomen skinfold and body weight. The prediction equation based on humerus breadth, femur breadth, abdomen skinfold and body weight proved to be accurate for estimating total body water ( $R$ $=.903 ; \mathrm{SEE}=1.276)$ than the combination of skinfolds $(\mathrm{r}=.706)$. Multiple regression equation was applied to the estimation of the total body water from these anthropometric measurements. Thus, the equation based on humerus breadth, femur breadth, abdomen skinfold and body weight could be instead of skinfolds to accurately estimate the criterion percent body fat.
\end{abstract}

(J. Physical Fitness Japan 1981, $30: 277 \sim 289$ )

\section{I. 緒}

身体を構成する活性組織と不活性組織をどのよ うにして求めるかについては，その方法が確立し ていない。除脂肪量や脂肪量を in vivo の状態で 推定する場合，水中体重測定法による体密度加ら 求める方法や尿クレアチニン排泄量, 体内総水分 量, ${ }^{40} \mathrm{~K}$ 量などを测定するととによって求める方 法などが採用されている。しかし，いずれも実験 等での複雑なテクニックを必要とし多人数を対象 とする場合には不適当である。多人数を対象とし たり,フィールドで身体構成成分を分析する場合 には簡便さが要求される。このような時, 脂肪量 を求める方法としては体密度と相関の高い皮脂厚 からの推定式を用いて体密度を算出し，乙の体密
度から脂肪量を推定するお汒が多く採用されてい る。例えば, Brožek and Keys ${ }^{2)}$, Pascale et al. ${ }^{16)}$ や Sloan ${ }^{23)}$ らは 2 部位あるいは 3 部仙の皮脂厚 が体密度と高い相関を示すととを指摘している。 Young and Bloadin ${ }^{30)}$, Sloan et al. ${ }^{22)}$, Katch and Michael ${ }^{9)}$, Wilmore and Behnke ${ }^{29)}$ や Katch and $\mathrm{McArdle}^{10)}$ らは皮脂原と周径，骨幅の合成变量 に高い相闕があることを報告して種々の体密度推 定式を俳成している。日本人の体密度推定式に関

しては, Nagamine and Suzuki ${ }^{14)}$, 佐藤 ${ }^{19)}$ と高崎 ら25などがある。以上の研究はすべて水中体重測 定法による体密度と人体計测值との関係から体脂 肪率を推定しているが, 肺内の残気量や腸内ガス に関して問題点を指摘する研壳者む多いようであ る。本研究に採用した体内総水分量は Sheng and

\footnotetext{
* 九州大学健康科学センター Institute of Health Science, Kyushu University, Ropponmatsu, Fukuoka
} 810 . 
Huggins?) が指摘しているように脂肪量の多少に よって変化する。一方, Pace and Rathbun ${ }^{15)}$, Schloerb et_al. ${ }^{20)}$, Forbes') ¿ Sheng and Huggins $^{7)}$ らが報告しているように除脂肪量に対する 体内総水分量の割合はほぼ一定である。とれらの 原理を応用し，体内総水分量を求めるととで, 逆 に脂肪量を求めることができる。本研究は，日本 人成人女子を対象に皮脂厚を基礎とした推定式に よる体脂肪率と体内総水分量より求めた体脂肪率 とを比較検討したすのである。また，人体計測值 を独立変量とするステップワイズ重回帰分析によ り体水分推定式を作成している。

\section{II. 方法}

被験者は健康な15名の女子大学生と12名の家庭 婦人である。人体計測と実験は 1980 年 9 月と 10 月 の 2 日間, 午前 9 時から12時までの間に実施し た。被験者の年齢や身体的特性は表 1 に示した。

体内総水分量 (TBW) の定量

重水 (deuterium oxide, $\mathrm{D}_{2} \mathrm{O}$ ) をトレーサーと した希釈法によって TBW を定量した。被験者 は朝食をと.らず，午前 9 時, 排尿, 排便後に体重 $1 \mathrm{~kg}$ につき $1 \mathrm{~g}$ の $\mathrm{D}_{2} \mathrm{O}$ (99.95\%) を20\%以下に 水で希釈したすのが経口投与された。投与後は比 較的安静を維持させ， $1 ， 2 ， 3$ 時間後の 3 回採 尿した。その間の飲食物摄取は禁止した。採尿し
た各時間の尿は $100^{\circ} \mathrm{C}$ で約 20 分間熱蒸留し, 冷却 管を通して約 $10 \mathrm{ml}$ のサンプルを探取した。採取 したサンプルは光路長 $0.073 \mathrm{~mm}$ の赤外分光光度 計用固定セル $\left(\mathrm{CaF}_{2}\right)$ に注入した。サンプル中の $\mathrm{D}_{2} \mathrm{O}$ 芣度は. Thornton and Condon ${ }^{26)}$, Trenner et al. ${ }^{27)}$, Turner et al. ${ }^{28)}$, Jones and MacKenzie ${ }^{8)}$ や Stansell and Mojica ${ }^{24)}$ らが報告している方法 に準して，260-50型日立赤外分光光度計によって 測定した。赤外分光光度計による $\mathrm{D}_{2} \mathrm{O}$ 濃度の測 定精度について, Graystone et al.5) ゃ Mendez et al. ${ }^{12)}$ は gas chromatography と同程度である ととを報告し，著者ら ${ }^{11)}$ あ高い精度で測定し得る ことを報告した。体内で希釈され平衡状態に達し た $\mathrm{D}_{2} \mathrm{O}$ 濃度 $\left(\% \mathrm{D}_{2} \mathrm{O}\right)$ と投与量 ( $\mathrm{g} \mathrm{D}_{2} \mathrm{O}$ given) を用いて TBW (liters) を次式によって求めた。

$\mathrm{TBW}$ (liters) $=\mathrm{g} \mathrm{D}_{2} \mathrm{O}$ given $/ \% \mathrm{D}_{2} \mathrm{O} \times 10$

体脂肪率 (\%Fat) の推定

\%Fat を推定する一つの方法として, triceps と subscapular の皮脂厚加 Nagamine and Suzu$\mathbf{k i}^{\left.\mathbf{1}^{4}\right)}$ の式によって体密度を算出し, Brozek et al. ${ }^{3)}$ の式に適用する方法を採用した。一方，除脂肪量 に対する TBW の割合は Pace and Rathbun ${ }^{15)}$, Schloerb et al. ${ }^{20)}$, Forbes ${ }^{4}$ ¿ Sheng and Huggins》らが報告しているように，73.2\%でほぼ一定 である。この原理を応用して，\%Fat を体水分率 (\%TBW) から次式によって求めた。

Table 1. Physical characteristics of subjects.

\begin{tabular}{|c|c|c|c|c|c|c|}
\hline \multirow{2}{*}{ Dimensions } & \multicolumn{6}{|c|}{ Women } \\
\hline & \multicolumn{2}{|c|}{$\begin{array}{c}\text { Students } \\
\text { Mean } \pm \text { SE }\end{array}$} & \multicolumn{2}{|c|}{$\begin{array}{l}\text { Housewives } \\
\text { Mean } \pm \text { SE }\end{array}$} & \multicolumn{2}{|c|}{$\begin{array}{c}\text { Total } \\
\text { Mean } \pm \text { SE }\end{array}$} \\
\hline Number & \multicolumn{2}{|c|}{15} & \multicolumn{2}{|c|}{12} & \multicolumn{2}{|c|}{27} \\
\hline Age (yr) & 20.6 & 0.12 & 36.1 & 0.57 & 27.5 & 1.53 \\
\hline Height $(\mathrm{cm})$ & 158.9 & 1.43 & 156.7 & 1.43 & 157.9 & 1.02 \\
\hline Weight (kg) & 54.4 & 2.75 & 51.2 & 1.31 & 53.0 & 1.64 \\
\hline $\mathrm{Ht} / \sqrt[8]{\mathrm{Wt}_{\mathrm{t}}}$ & 42.1 & 0.51 & 42.2 & 0.36 & 42.2 & 0.32 \\
\hline Humerus breadth $(\mathrm{cm})$ & 5.7 & 0.10 & 5.6 & 0.07 & 5.7 & 0.06 \\
\hline Femur breadth $(\mathrm{cm})$ & 8.7 & 0.15 & 8.9 & 0.13 & 8.8 & 0.10 \\
\hline Arm girth $(\mathrm{cm})$ & 24.6 & 0.69 & 23.8 & 0.47 & 24.2 & 0.43 \\
\hline Calf girth (cm) & 34.8 & 0.78 & 33.3 & 0.56 & 34.1 & 0.51 \\
\hline \multicolumn{7}{|l|}{ Skinfolds (mm) } \\
\hline Triceps & 18.4 & 1.74 & 15.9 & 0.91 & 17.3 & 1.06 \\
\hline Subscapular & 20.1 & 1.93 & 16.3 & 1.23 & 18. 4 & 1.24 \\
\hline Suprailiac & 24.2 & 2.30 & 18.7 & 1.71 & 21.8 & 1.55 \\
\hline Abdomen & $24: 2$ & 2.14 & 24.0 & 1.92 & 24.1 & 1.44 \\
\hline
\end{tabular}


Table 2. Body composition of subjects.

\begin{tabular}{|c|c|c|c|c|c|c|c|}
\hline \multicolumn{2}{|c|}{ Compartment } & \multicolumn{2}{|c|}{$\begin{array}{c}\text { Students } \\
\text { Mean } \pm \text { SE }\end{array}$} & \multicolumn{2}{|c|}{$\begin{array}{l}\text { Housewives } \\
\text { Mean } \pm \mathrm{SE}\end{array}$} & \multicolumn{2}{|c|}{$\begin{array}{c}\text { Total } \\
\text { Mean } \pm S E\end{array}$} \\
\hline \multirow{2}{*}{ Total body water } & $(l)$ & 25.4 & 0.85 & 25.2 & 0.61 & 25.3 & 0.53 \\
\hline & (\%) & 47.3 & 1.06 & 49.4 & 0.89 & 48.2 & 0.73 \\
\hline Body fat & (\%) & 35.3 & 1.45 & 32.4 & 1.22 & 34.0 & 0.99 \\
\hline Fat-free mass & (\%) & 64.6 & 1.45 & 67.5 & 1.22 & 65.9 & 0.99 \\
\hline Mineral mass & (\%) & 4.5 & 0.10 & 4.7 & 0.08 & 4.6 & 0.06 \\
\hline Cell solids & (\%) & 12.8 & 0.28 & 13.3 & 0.24 & 13.0 & 0.19 \\
\hline
\end{tabular}
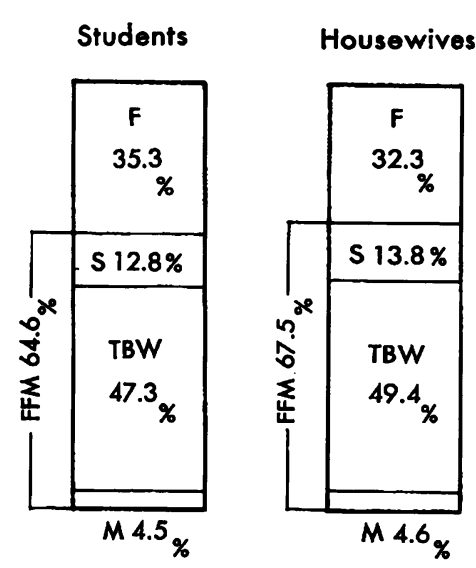

Total

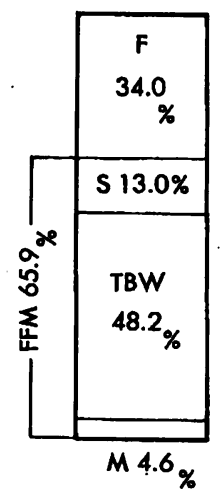

Fig. 1. Body composition of subjects.

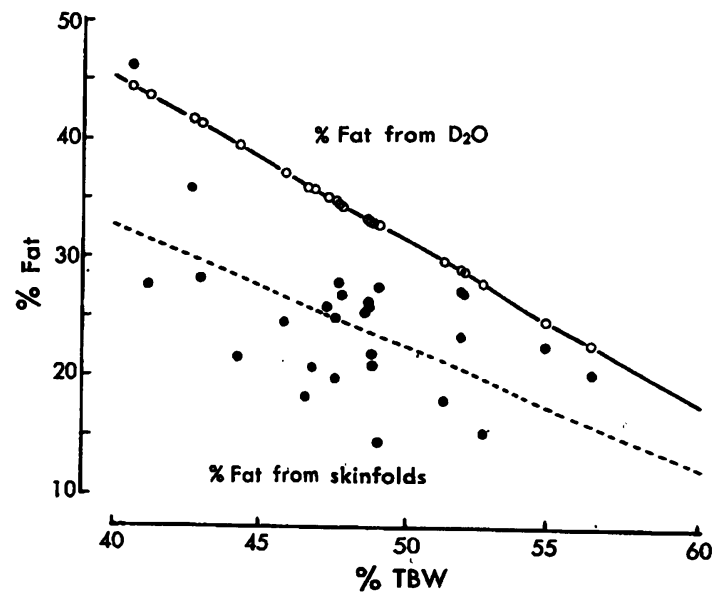

Fig. 2. Relationship of percent body fat to percent total body water and comparison of percent body fat as determined by two methods.

$$
\% \text { Fat }=100-\% \mathrm{TBW} / 0.732
$$

\%Fat を求める第三の方法としてのクレアチニ ン法は Bonsnes and Taussky ${ }^{12}$ の方法に準じて, 100-10型日立分光光度計によって测定した。24時
間尿中のクレアチニン排泄量から次式によって除 脂肪量 (FFM) を求め, \%Fat を推定した。

$\mathrm{FFM}(\mathrm{kg})=7.38+0.02908 \mathrm{cr} .(\mathrm{mg} /$ day $)$

$\%$ Fat $=100-\%$ FFM

体重に占める FFM, Cell Solids (S) と Mineral Mass (M) の割合は Hamwi and Urback $\left.{ }^{6}\right)$ の 式によって求めた。

$\% \mathrm{FFM}=\% \mathrm{TBW} / 0.732$

$\% \mathrm{~S}=\% \mathrm{FFM}-(\% \mathrm{TBW}+\% \mathrm{M})$

$\% \mathrm{M}=0.07 \times \% \mathrm{TBW} / 0.732$

次に, $\mathrm{D}_{2} \mathrm{O}$ 希釈法によって得られた TBW と 種々の人体計測値とのステップワイズ重回帰分析 を行ない体水分推定式を作成した。統計的分析に は九州大学大型計算機センターFACOM M-200 を使用した。

\section{III. 桔 果}

被験者の身体的特性に関して，平均值之標準誤 差を表 1 亿示している。本研究の被験者は平均年 龄20.6才の女子大学生之平均年龄36.1才の家庭婦 人である。女子大学生と家庭婦人の人体計測值及 び皮脂厚の平均值間には統計的有意差は認められ なかった。

表 2 は $\mathrm{D}_{2} \mathrm{O}$ 希釈法によって定量された．TBW 之 TBW から推定した各身体構成成分の平均值 を示している。女子大学生と家庭婦人の平均値間 には統計的有意差は認められなかった。

因 1 は体重を $100 \%$ として各身体構成成分の占 める割合を示したものである。

図 2 は $\mathrm{D}_{2} \mathrm{O}$ 希釈法による \%TBW とてれを 利用して推定した \%Fat，そして皮厚脂を基礎よ した \%Fat との関係を比較し、両推定法による \%Fat 間の差をみたあのである。 $\mathrm{D}_{2} \mathrm{O}$ 希釈法で は，\%TBW が同一の個体はすべて \%Fat が同 
Table 3. Comparison of percent body fat as determined by three methods.

\begin{tabular}{c|c|c|c|c}
\hline Subject & Age & $\begin{array}{c}\text { \% Fat from } \\
\text { Total Body Water* }\end{array}$ & $\begin{array}{c}\text { \% Fat from } \\
\text { Skinfolds** }\end{array}$ & $\begin{array}{c}\text { \% Fat from } \\
\text { Creatinine*** }\end{array}$ \\
\hline a & 27 & 22.9 & 14.8 & 20.4 \\
b & 28 & 28.4 & 18.1 & 28.5 \\
c & 25 & 23.2 & 20.0 & 32.8 \\
d & 24 & 31.3 & 19.4 & 34.9 \\
\hline
\end{tabular}

* by $\mathrm{D}_{2} \mathrm{O}$ in this study

** by the formula of Nagamine \& Suzuki (1964) using triceps and subscapular skinfolds

*** by the urinary creatinine concentration in this study

Table 4. Correlation coefficients between percent body fat and skinfolds.

\begin{tabular}{l|c}
\hline \multicolumn{1}{c|}{ Variable } & $\begin{array}{c}\text { Correlation with } \\
\text { \%6Fat from } \mathrm{D}_{2} \mathrm{O}\end{array}$ \\
\hline Skinfold, mm & \\
Triceps & .605 \\
Subscapular & .523 \\
Suprailiac & .533 \\
Abdomen & .650 \\
96Fat & \\
Triceps + Subscapular & .600 \\
\hline
\end{tabular}

Table 5. Correlation coefficients between total body water and various body dimensions.

\begin{tabular}{l|c}
\multicolumn{1}{c|}{ Dimensions } & $\begin{array}{c}\text { Correlation with } \\
\text { TBW }\end{array}$ \\
\hline Height, cm & .599 \\
Weight, kg & .865 \\
Ht/ $\sqrt[8]{\mathrm{Wt}}$ & -.570 \\
Humerus breadth, cm & .779 \\
Femur breadth, cm & .808 \\
Arm girth, cm & .749 \\
Calf girth, cm & .764 \\
Skinfolds, mm & \\
Triceps $\left(\mathrm{X}_{1}\right)$ & .596 \\
Subscapular $\left(\mathrm{X}_{2}\right)$ & .698 \\
Suprailiac $\left(\mathrm{X}_{3}\right)$ & .468 \\
Abdomen $\left(\mathrm{X}_{\mathbf{1}}\right)$ & .577 \\
\hline
\end{tabular}

一である。しかし，皮脂厚を基礎とした \%Fat と の関係では，\%TBW が同一であっても\%Fatに かなりのバラッキがみられた。皮脂厚を基礎とし た \%Fat の推定傾向線は $\mathrm{D}_{2} \mathrm{O}$ 希釈法の直線之 ほぼ平行ではあるが，\%Fat を低く推定するとと が明らかになった。 $\mathrm{D}_{2} \mathrm{O}$ 希釈法と皮脂厚を基礎 とした推定式の 2 方法によって得られた \%Fat 間
の相関係数は 0.600 で，それほど高いすのではな 加た。

表 3 は 4 名の被験者について㽷クレアチニン排 泄量加 FFM を求め，その值加 \%Fat を計 算して上記の 2 方法と比較した結果である。クレ アチニン法によって得られた 4 名の \%Fatはすべ て皮脂厚を基礎としたものより大きく, 被験者 $\mathrm{C}$ を除いてすへて $\mathrm{D}_{2} \mathrm{O}$ 希釈法による $\% \mathrm{Fat}$ と近似 していた。

表 4 は $\mathrm{D}_{2} \mathrm{O}$ 希釈法による \% Fat と皮脂厚との 相関をみたあのであり，どの部位すそれほど高い 相関係数は示さなかった。 Nagamine and Suzu$\mathrm{ki}^{14)}$ の推定式に採用されている triceps と subscapular の合成変量との相関係数 $(r=0.600)$ は abdomen との相関係数 $(r=0.650)$ よりむしろ 小さかった。

表 5 は TBW と人体計測值及び皮脂厚との相 関をみたあのである。比較的高い相関係数は，体 重 $(r=0.865)$, 大腿骨端幅 $(r=0.779)$, 上腕骨 端幅 ( $r=0.808)$ にみられ, Nagamine and Suzu$\mathrm{ki}^{14)}$ の推定式に採用されている皮脂厚の合成変 量との相関は $r=0.706$ であった。

そこで, 表 5 に示した変量を独立変量として TBW とのステップワイズ重回帰分析を試みた。 その結果，表 6 に示すように，重相関係数(R)が 0.903 で, 推定の標準誤差 (SEE) が 1.276 であ る推定式が求められた。

表 7 はこの推定式を被験者に適用した時の $\mathrm{TBW}$ の推定成績の平均值と $\mathrm{D}_{2} \mathrm{O}$ 希釈法によっ て定量された TBW の平均值とを比較している。 平均値は両者とも $25.3 l$ で等しく, 両者間の差の 平均値は 非常に小さかった。一方, 推定された $\mathrm{TBW}$ と $\mathrm{D}_{2} \mathrm{O}$ 希釈法によって定量された TBW 
Table 6. Multiple regression equation for predicting total body water.

\begin{tabular}{l|c|c|c}
\multicolumn{1}{c|}{ Variable } & $\begin{array}{c}\text { Regression } \\
\text { Coefficient }\end{array}$ & $\begin{array}{c}\text { Multiple } \\
\text { Correlation } \\
(\mathrm{R})\end{array}$ & $\begin{array}{c}\text { Standard Error } \\
\text { of Estimate }\end{array}$ \\
\hline Constant & -8.704 & .903 \\
$(\mathrm{p}<0.001)$ & 1.276 \\
(1) Humerus breadth, cm & 1.801 & \\
(2) Femur breath, cm & 1.798 & \\
(3) Abdomen skinfold, mm & -0.092 & \\
(4) Weight, kg & 0.190 & & \\
\hline
\end{tabular}

Table 7. Means and differences between determined and estimated total body water and percent body fat.

\begin{tabular}{|c|c|c|c|c|c|c|}
\hline & \multicolumn{2}{|c|}{$\begin{array}{l}\text { From } \mathrm{D}_{2} \mathrm{O}(1) \\
\text { Mean } \pm \mathrm{SE}\end{array}$} & \multicolumn{2}{|c|}{$\begin{array}{c}\text { From Prediction Equation*(2) } \\
\text { Mean } \pm \mathrm{SE}\end{array}$} & \multicolumn{2}{|c|}{$\begin{array}{l}\text { Difference (1) }-(2) \\
\text { Mean } \pm \mathrm{SE}\end{array}$} \\
\hline TBW (l.) & 25.3 & 0.53 & 25.3 & 0.48 & 0.017 & 0.2259 \\
\hline $96 \mathrm{Fat} * *$ & 34.0 & 0.99 & 34.0 & 0.81 & -0.058 & 0.5966 \\
\hline
\end{tabular}

* $\mathrm{TBW}=-8.704+1.801$ (Humerus breadth, $\mathrm{cm}$ ) +1.798 (Femur breadth, $\mathrm{cm}$ ) -0.092 (Abdomen skinfold, $\mathrm{mm}$ ) +0.190 (Weight, $\mathrm{kg}$ )

$* * \% \mathrm{Fat}=100-\% \mathrm{TBW} / 0.732$

の両者から求めた \%Fat についても同様に比較し ている。平均值は $34.0 \%$ と $34.0 \%$ で，両者間の差 の平均值は $-0.058 \%$ であり, \%Fat であ高い一 致度を示した。

\section{IV. 考察}

本研究の被験者である女子大学生 15名の体位 は, 日本人の標準值 ${ }^{18)} よ り$ 身長で $3.2 \mathrm{~cm}$, 体重 で $3.6 \mathrm{~kg}$ 大きな值を示し，家庭婦人 12 名は，身 長で $3.7 \mathrm{~cm}$ 標準値 ${ }^{18)}$ より大きいすのの体重では $0.9 \mathrm{~kg}$ 小さな值を示している。Ponderal 指数で は両群とも標準値 ${ }^{18}$ に近似した値を示している。 女子大学生の皮脂厚は, Nagamine and Suzuki ${ }^{14)}$ や佐藤 ${ }^{19}$ らが報告している日本人21才女子の值よ りすべての部位において大きい。また，Pollock

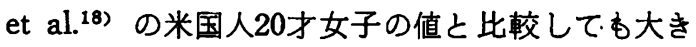
く, とくに subscapular の值はその差が $4.8 \mathrm{~mm}$ と大きい。家庭婦人の皮脂厚は Pollock et al. ${ }^{18)}$ の米国人中高年婦人の值之比較すると本研究の值 は明らかに小さい。従って, 被験者の体位に関し ては，身長と体重が標準值 ${ }^{18)}$ よりやや大きく，皮 脂厚に関しては，女子大学生の值が大きく，家庭 婦人の皮脂厚は標準的であるといえる。

体組成に関しては，同一推定方法によって得ら れた值を比較することが重要である。例えば,
$\mathrm{D}_{2} \mathrm{O}$ 希瀵法による $\mathrm{TBW}$ から得られた $\% \mathrm{Fat}$ と 皮脂厚を推定の基礎にした \%Fat とを比較すると とは妥当ではない。 $\mathrm{D}_{2} \mathrm{O}$ 希粎法による TBW の 測定は, 体内の全脂肪組織に対応するすのと考え られるが, 皮脂厚はその一部にすきない。従っ て, 本研究では TBW から得られた体組成推定 值との比較が望ましい。最近の日本人の $\mathrm{D}_{2} \mathrm{O}$ 希 採法による \%Fat と \% TBW の推定值は PicónReátegui et al. ${ }^{17)}$ が報告しているのみである。彼 らの19才女子大学生の推定値と本研究の女子大学 生の值とを比較すると, 明らかに本研究の \%Fat が大きく，\%TBW の值が小さい。家庭婦人に関 しては報告がない。そてで, Pi6n-Reategui et al..7) の Ainu（平均年齢30.0才，\%Fat $=28.0, \% \mathrm{TBW}$ =52.6) と Shephard et al. ${ }^{21)}$ の Eskimo（年龄 $30 \sim 39$ 才, $\% \mathrm{Fat}=26.0, \% \mathrm{TBW}=54.2 ）$ 亿関す る推定値之本研究の推定値之を比較すると, 本研 究の \%Fat が大きいととがわかる。しかし，被験 者両群の身体的特性には人体計測値及び体組成推 定值に関して差が認められず，乙の両群は本研究 の対象としては同質であると考えることができ る。そこで, 両群を総合して $\mathrm{D}_{2} \mathrm{O}$ 希釈法による $\% \mathrm{Fat}$ と皮脂厚を基礎とした $\% \mathrm{Fat}$ 間の差を検討 した。 $\mathrm{D}_{2} \mathrm{O}$ 希釈法による \%Fat の平均値は34.0 \%（標準誤差5.18）であり, 皮脂厚を基礎とした 
\%Fat の平均値は 24.4\%（標準誤差 6.39）であ る。従って，との年齢層（20４0才）の女子の\% Fat を推定するのに, Nagamine and Suzuki ${ }^{14)} の$ 式によって求めた体密度を Brožek et $\mathrm{al}^{\mathrm{s})}$ の式 に適用した場合は $\mathrm{D}_{2} \mathrm{O}$ 希釈法による体内総水分 量を基礎にして得られた \%Fat より約 $10 \%$ 過小推 定することが明らかである。一方, 第三の方法之 して採用したクレアチニン法の結果からも， $\mathrm{D}_{2} \mathrm{O}$ 希釉法が \%Fatを不適当に高く推定するのではな く，むしろ成人女子に関しては皮脂厚を基礎とし た推定式が\%Fat を過小推定することが明らかで ある。皮脂厚を基礎とした推定式は，水中体重測 定法による体密度との関係加ら確立されているす のである。従って, 同一被験者の体密度と体内総 水分量を測定して \%Fat を推定し，比較する必要 がある。本研究では，皮脂厚を基礎とした推定式 が, $\mathrm{D}_{2} \mathrm{O}$ 希釈法による推定值より\% Fat を過小推 定するという外的基準は尿中クレアチニン排泄量 からの推定值である。従って, 被験者の体密度を 測定しないと断定的なととはいえないが，17年前 の日本人を対象とした推定式が現代日本人に適用 できるとは考えにくい。そとで，人体計測值から $\mathrm{D}_{2} \mathrm{O}$ 希釈法によって求められる \%Fat（体内の全 脂肪組織に対応していると考えられる）に近似し た値を知るための推定式を統計的方法によって作 成している。この式は, 体内総水分量を推定する あのであり，乙の式を体組成の推定に適用するに は, 除脂肪量に対する水分の割合が一定であると いう原理に立脚しなりればならない。一方，本研 究の対象が限定されている点も考慮すると，ての 推定式の普偏妥当性には疑問がある。しかし，本 研究の結果が示すように，現在広く採用されてい る皮脂厚を基礎とした体脂肪率の推定式は％ Fat を過小推定する可能性があると考えられるので, 今後改良される必要がある。

\section{V. 摘 要}

本研究は，日本人成人女子27名を対象に皮脂厚 を基礎とした体脂肪率 $(\% \mathrm{Fat})$ 推定法と $\mathrm{D}_{2} \mathrm{O}$ を トレーサーとして 体内総水分量 (TBW) を求め 体脂肪率を推定する $\mathrm{D}_{2} \mathrm{O}$ 希釈法とを比較検討し た。

結果は次のように要約できる。
1) $\mathrm{D}_{2} \mathrm{O}$ 希釈法では, \% $\% \mathrm{TBW}$ が同一の個体 はすへて \%Fat が同一であるが，皮脂厚を基礎 とした \%Fat との関係では，\%TBW が同一で あってあ \%Fatにかなりのバラッキがみられた。

2）皮脂厚を基礎とした \%Fat の推定傾向線は $\mathrm{D}_{2} \mathrm{O}$ 希釈法の直線とほほ平行ではあるが，\%Fat を約10\%過小推定するととか明らかになった。

3） $\mathrm{D}_{2} \mathrm{O}$ 希釈法と皮脂厚を基碟とした推定式 の 2 方法によって得られた $96 \mathrm{Fat}$ 間の相関係数は 0.600 で，それほど高いあのではなかった。

4）クレアチニン法によって得られた％Fat は 皮脂厚を基礎としたすのより大きく， $\mathrm{D}_{2} \mathrm{O}$ 希釈 法による \%Fat と近似していた。

5） $\mathrm{D}_{2} \mathrm{O}$ 希勫法による 宆 Fat と皮脂厚との相 関は，どの部位もそれほど高くなく，Nagamine and Suzuki の推定式に採用されている triceps 之 subscapular の合成変量との相関係数 $(r=0.600)$ は abdomen との相関係数 $(r=0.650)$ よりむし ろ小さかった。

6) TBW と比較的高い相関は, 体重 $(r=$ $0.865)$, 大腿骨端幅 $(r=0.779)$, 上腕骨端幅 $(r=$ 0.808)にみられた。

7）人体計剆値及び皮脂厚と TBW との重回 掃分析の結果, 重相関係数 (R) が 0.903 , 推定の 標準誤差 (SEE) が 1.276 である体水分推定式が 求められた。

TBW (liters) $=-8.704+1.801$ (Humerus breadth, $\mathrm{cm}$ ) +1.798 (Femur breadth, $\mathrm{cm}$ ) -0.092 (Abdomen skinfold, $\mathrm{mm}$ ) +0.190 (Weight, $\mathrm{kg}$ )

本研究を実行するにあたって, 赤外分光光度計に よる $\mathrm{D}_{2} \mathrm{O}$ 濃度の湖定に関しては九州大学教緟部化 学教室立田清朗教授 (九州大学揵康科学センタ一客 員教授）から愳篤なる御指導を睗わった。記して深 甚なる謝意を表したい。

（受付 昭和56年 4 月27日）

\section{参考文。献}

1) Bonsnes, R.W. and Taussky, H.H. (1945) : On the calorimetric determination of creatinine by the Jaffe reaction, J. Biol. Chem. 158 : 581-591.

2) Brožek, J. and Keys, A. (1951) : The evaluation of leanness-fatness in man : norms 
and interrelationships. Brit. J. Nutr. 36 : 32-34.

3) Brožek, J., Grande, F., Anderson, J. T. and Keys, A. (1963) : Densitometric analysis of body composition : Revision of some quantitative assumptions. Ann. N. Y. Acad. Sci. 110 : 113-140.

4) Forbes, G. B. (1962) : Methods for determining composition of the human body with a note on the effect of diet on body composition. Pediatrics 29 : 477-494.

5) Graystone, J., Seitchik, J., Milch, R., Shulman, G.P. and Cheek, D. B. (1967) : Measurement of $\mathrm{D}_{2} \mathrm{O}$ in plasma water by freezing point elevation, falling drop, infra-red absorption, and gas chromatography. J. Lab. \& Clin. Med. 69 : 885-892.

6) Hamwi, G. J. and Urbach, S. (1953) : Body compartments. Their measurement and application to clinical medicine. Metab. 2 : 391-403.

7) Hwai-Ping Sheng and Huggins, R.A. (1979) : A review of body composition studies with emphasis on total body water and fat. Am. J. Clin. Nutr. $32: 630-647$.

8) Jones, R.N. and MacKenzie, M.A. (1960): Determination of deuterium in organic compounds by infrared spectrophotometry. Talanta $3: 356-363$.

9) Katch, F. I. and Michael, E. D. (1968): Prediction of body density from skinfold and girth measurements of college females. J. Appl. Physiol. 25 : 92-94.

10) Katch, F. I. and McArdle, W. D. (1973): Prediction of body density from simple anthropometric measurements in collegeage men and women. Human Biol. 45: 445-454.

11) Komiya, S., Komuro, T. and Tateda, A. (1981) : Determination of the total body water by $\mathrm{D}_{2} \mathrm{O}$ dilution using urine samples and infrared spectrophotometry. 体育学研究 26 : 161-167.

12) Mendez, J., Prokop, E., Picón-Reátegui, E., Akers, R. and Buskirk, E. R. (1970) : Total body water by $\mathrm{D}_{2} \mathrm{O}$ dilution using saliva samples and gas chromatography. J. Appl. Physiol. 28 : 354-357.

13）飯塚敛雄他（1975）：日本人の体力祭準值 不 晰堂, 東京, 27-69.

14) Nagamine, S. and Suzuki, S. (1964): Anthropometry and body composition of Japanese young men and women. Human Biol. 36 : 8-15.

15) Pace, N. and Rathbun, E.N. (1945) : Studies on body composition. III. The body water and chemically combined nitrogen content in relation to fat content. J. Biol. Chem. 158 : 685-691.

16) Pascale, L.R., Grossman, M.I., Sloane, H.S. and Frankel, T. (1956) : Correlations between thickness of skin-folds and body density in 88 soldiers. Human Biol. 28 : 165-176.

17) Picón-Reátegui, E., Buskirk, E. R., Doi, K., Kuroshima, A. and Hiroshige, T. (1979): Anthropometric characteristics and body composition of Ainu and other Japanese : comparison with other racial group. Am. J. Phys. Anth. $50: 393-400$.

18) Pollock, M. L., Laughridge, E. E., Coleman, B., Linnerud, A. C. and Jackson, A. (1975) : Prediction of body density in young and middle-aged women. J. Appl. Physiol. 38 : 745-749.

19）佐藤光毅，（1975）：日本人の Body Fat Mass に関する研究一青年期における Body Fat Mass について一体力科学 24 : 134-150.

20) Schloerb, P. R., Friis-Hansen, B. J., Edelman, I.S. and Moore, F. D. (1950): The measurement of total body water in the human subject by deuterium oxide dilution J. Clin. Invest. 29 : 1296-1310.

21) Shephard, R. J. and Rode, A. (1973): On the body composition of the Eskimo. Europ. J. appl. Physiol. $32: 3-15$.

22) Sloan, A. W., Burt, J. J. and Blyth, C. S. (1962) : Estimation of body fat in young women. J. Appl. Physiol. 17 : 967-970.

23) Sloan, A. W. (1967): Estimation of body fat in young men. J. Appl. Physiol. 23 : $311-315$. 
24) Stansell, M.J. and Mojica, L. (1968): Determination of body water content using trace levels of deuterium oxide and infrared spectrophotometry, Clin. Chem. 14 : 1112-1124.

25）高崎裕治，鎌滝昭男，山崎昌広（1979）：口本 人青年男子の体密度推定式, 人類学:雑誌 87 : 439-444.

26) Thornton, V. and Condon, F.E. (1950): Infrared spectrometric determination of deuterium oxide in water. Anal. Chem. $22: 690-691$.

27) Trenner, N. R., Arison, B. and Walker, R. W. (1953) : A general infrared spectrophotometric technique for the determi- nation of deuterium in organic compounds. Appl. Spectroscopy $7: 166-171$.

28) Turner, M. D., Neely, W. A. and Hardy, J. D. (1960) : Rapid determination of deuterium oxide in biological fluids. J. Appl. Physiol. 15 : 309-310.

29) Wilmore, J. H. and Behnke, A. R. (1970): An anthropometric estimation of body density and lean body weight in young women. Am. J. Clin. Nutr. 23 : 267-274.

30) Young, C. M. and Blondin, J. (1962) : Estimating body weight and fatness of young women. J. Amer. Diet. Assoc. 41 : $452-455$. 